\title{
Isolation and Identification of Indigenous Yeast Strain and Its Potential for Yeast Extract Production
}

\author{
S.Mahilrajan ${ }^{1}$, C. J. Emmanuel ${ }^{* 2}$, and S. Srivijeindran ${ }^{1}$ \\ ${ }^{1}$ Palmyrah Research Institute, Jaffna, JA 40000, Sri Lanka \\ ${ }^{2}$ Department of Botany, Faculty of Science, University of Jaffna, Jaffna, JA 40000, Sri Lanka \\ *Email: jeyaseelan.ec@univ.jfn.ac.lk
}

\begin{abstract}
The growing demand for protein-rich food forces humans to search for alternative protein sources. Yeasts are among the preferred candidates due to their well-balanced source of amino acids and vitamins. The present study aimed to identify an indigenous yeast strain that can be used as a protein source. Yeast strains were isolated from Palmyrah toddy sediments collected from different regions in the Jaffna Peninsula. One yeast strain, named A3, was selected as a potential strain based on the maximum cell size and optical density among the 55 yeast strains isolated. The biochemical analysis and sequencing of the ITS region (including 5.8S rRNA gene) and the LSU rRNA gene D1/D2 domains confirmed the yeast isolate as a strain of Saccharomyces cerevisiae. The optimum growth conditions for the yeast strain were determined using Taguchi $\mathrm{L}_{16}$ orthogonal array. Yeast cell autolysis was conducted with and without papain, and the yield of soluble matter and total protein were measured. The strain yielded a maximum of $70.7 \%$ soluble mater and $56.9 \%$ of total protein when autolysis with papain. The yield is significantly higher $(\mathrm{p}<0.05)$ than obtained with the baker's yeast used in the control experiment.
\end{abstract}

Keywords — Palmyrah toddy, Saccharomyces cerevisiae, single-cell protein, yeast.

\section{INTRODUCTION}

The increasing population in developing countries is expected to create a high demand for protein-rich food by 2050 (Boland et al., 2013). Therefore, new initiatives will be required to produce the necessary quantities of high-quality protein. Various microbes and algae can be good sources for protein, preferably those containing more than $30 \%$ protein in their biomass and providing a healthy balance of essential amino acids (Ritala et al., 2017).

Yeasts are significantly valuable in human culture, and they are widely used to produce alcoholic beverages and bakery products. Since the yeast contains 30-60\% protein, they have been used as single-cell protein (Anupama and Ravindra, 2000; Nasseri et al., 2011). Spent brewer's yeast (Saccharomyces cerevisiae) have been sold for more than a century in yeast extracts such as Marmite ${ }^{\circledR}$ (Unilever and Sanitarium Health Food), Vegemite ${ }^{\circledR}$ (Bega Cheese Ltd.), Cenovis $^{\circledR}$ (Gustav Gerig AG), and Vitam- ${ }^{\circledR}$ (VITAM HefeProdukt $\mathrm{GmbH}$ ). The yeast extracts are also a good source of thiamine, riboflavin, biotin, niacin, pantothenic acid, pyridoxine, choline, streptogenin, glutathione, folic acid and p-aminobenzoic acid (Frazier and Westhoff, 1988). The extract obtained from yeast cultures is widely used in the food industry to enhance or provide a meaty flavour to food products (Tanguler and Erten, 2008).

Mostly, the yeast extract is prepared from baker's yeast or spent brewer's yeast by autolysis. At an elevated temperature, endogenous enzymes degrade yeast cells. The yield of extract in standard autolysis usually varies between 19 to $56 \%$ for different types of yeast (Sugimoto, 1974; Kollar et al., 1991; Vukasinovic Milic et al., 2007). Extract yields can sometimes be improved by adding commercial food-grade proteases such as papain (Verduyn et al., 1999). Several studies have been conducted to optimise factors that influence protein extraction from different types of yeasts (Hongpattarakere and H-kittikun, 1995; Taran and Bakhtiyari, 2013; Lapeña et al., 2020).

Palmyrah toddy is a sweetish, milky white, vigorously effervescent, mildly alcoholic beverage obtained from Palmyrah palm (Borassus flabellifer L.). Since ancient times, toddy has been consumed by the indigenous people, similar to wine in Europe. The toddy is collected by tapping the male or female inflorescence of the Palmyrah palm. The sweet sap oozed from inflorescence is collected in pods, and the sap undergoes spontaneous fermentation by air-borne yeast isolates. The yeast sediment at the bottom of the fermentation tank has been considered as an inconvenient waste, and it is left out as waste material. About 30 years ago, a study conducted based on yeast's biochemical and morphological characteristics revealed the association of Saccharomyces cerevisiae, Kloeckera apiculata, Schizosaccharomyces pombe and Saccharomyces chevalieri in the sediments of the toddy (Theivendirarajah and Chrystopher, 1987). The present study aimed to isolate and identify a potential yeast isolate from the toddy sediment and to increase protein yield from that isolate by optimising the growth and autolysis on a laboratory scale.

\section{MATERIALS AND METHODOS}

\section{A. Toddy Sample Collection and of yeast isolation}

Toddy samples with yeast sediments were collected from Palm development cooperative societies (PDCS) in nine different regions, namely Maruthankeny, Chunnakam, 
Achchuvely, Chavachcheri, Manipay, Pandaththarippu, Nelliyady, Kodikamam and Kayts in Jaffna district, Sri Lanka. In each PDCS, five different samples were collected between January to March 2018. The yeast sediments were serially diluted up to a notional $10^{-4}$ dilution in sterile saline $(0.85 \% \mathrm{NaCl})$. The suspension was transferred on yeast extract peptone dextrose agar (YEPDA) medium (1 L medium contain yeast extract $5.0 \mathrm{~g}$, peptone $10.0 \mathrm{~g}$, dextrose $20.0 \mathrm{~g}$ and agar $2.5 \mathrm{~g}$ ) by spread plate method, and the plates were incubated at $28{ }^{\circ} \mathrm{C}$ for 3-5 days. Morphologically distinct fifty-five colonies were sub-cultured on a fresh medium of the same composition.

\section{B. Selection of potential yeast isolate based on cell size and optical density in suspension}

The isolates were grown in yeast extract peptone dextrose (YEPD) broth (1 L medium contains yeast extract $5.0 \mathrm{~g}$, peptone $10.0 \mathrm{~g}$, dextrose $20.0 \mathrm{~g}$ ) at $28{ }^{\circ} \mathrm{C}$ in a shaker at 100 $\mathrm{rpm}$. After $48 \mathrm{~h}$ of incubation, each isolate's cell diameter or length was measured using an ocular micrometre. In addition, the optical density $(600 \mathrm{~nm})$ of the aliquots of yeast cell suspensions was measured using UV - Vis spectrophotometer (Thermo Scientific ${ }^{\mathrm{TM}}$ GENESYS ${ }^{\mathrm{TM}}$ 10S) after three days of incubation. Finally, an isolate with the largest cell size and highest density in suspension was selected for further screening and identification.

\section{Biochemical characterisation of the yeast isolate}

The isolate was tested for carbohydrate fermentation, carbon assimilation, temperature tolerance and urease production. All the experimental procedures were followed as described by Kurtzman et al. (2011a). For the carbohydrate fermentation, the isolate was inoculated in YEP broth with bromothymol blue and different sugars, namely sucrose, Dgalactose, glucose, lactose, maltose and raffinose. Carbon assimilation of the yeast isolate was tested by inoculating in yeast nitrogen base medium, which was incorporated with different carbon compounds (Glucose, mannitol, ribose, galactose, myo-inositol, lactose, xylose, inulin, sucrose, Darabinose, maltose, ethanol, methanol, glycerol and Larabinose). The isolate was grown on YEPD medium at temperatures $19,25,30,37$ and $45^{\circ} \mathrm{C}$ to find optimum growth temperature. Similarly, Christensen urea agar medium (with $20 \%$ ) at $\mathrm{pH} 6.8$ was used to test the hydrolysis of urea.

\section{Molecular identification of the yeast isolate}

\section{D.1. DNA extraction}

DNA isolation was performed as described by Senses-ergul et al. (2006). The yeast isolates cultured on tryptone glucose yeast extract (TGY) agar for $24 \mathrm{~h}$ at $30{ }^{\circ} \mathrm{C}$ was suspended and washed in $1 \mathrm{~mL}$ of sterile distilled water. Then the cells were collected by centrifugation at $14,000 \mathrm{rpm}$ for $2 \mathrm{~min}$ and $200 \mu \mathrm{L}$ of breaking buffer (2\% (v/v) Triton X-100, $1 \%(\mathrm{w} / \mathrm{v})$ SDS, $100 \mathrm{mM} \mathrm{NaCl}, 10 \mathrm{mM}$ Tris-HCl pH 8.0, $1 \mathrm{mM}$ EDTA). Glass beads (diameter $0.45-0.50 \mathrm{~mm}$ ), $200 \mu \mathrm{L}$ of buffered phenol, chloroform and isoamyl alcohol (25:24:1, $\mathrm{v} / \mathrm{v})$ were added. After vortexing for $3 \mathrm{~min}, 200 \mu \mathrm{L} \mathrm{TE}$ buffer (10 mM Tris-HCl pH 8.0, 1 mM EDTA) was added to the mixture. It was followed by vortexing for $1 \mathrm{~min}$ and centrifugation at $14,000 \mathrm{rpm}$ for $5 \mathrm{~min}$. The upper phase was pipetted into $1 \mathrm{~mL}$ of ice-cold $96 \%$ ethanol and mixed. The precipitated nucleic acids were collected by centrifugation at $14,000 \mathrm{rpm}$ for $5 \mathrm{~min}$, and the pellet was redissolved in 50 $\mu \mathrm{L}$ TE buffer. For the digestion of RNA, $3 \mu \mathrm{L}$ RNAse (10 $\mu \mathrm{g} / \mathrm{mL}$ ) (Sigma) was added, and the mixture was incubated at $37{ }^{\circ} \mathrm{C}$ for $30 \mathrm{~min}$. After incubation, the DNA was precipitated in $1 \mathrm{~mL}$ of ice-cold $96 \%$ ethanol and centrifuged at $14,000 \mathrm{rpm}$ for $5 \mathrm{~min}$. The pellet was redissolved in $50 \mu \mathrm{L}$ TE buffer and stored until use at $-20^{\circ} \mathrm{C}$.

\section{D.2. PCR amplification and sequencing}

The sequences of the ITS region (including 5.8S rRNA gene) and the LSU rRNA gene D1/D2 domains were PCR amplified from the genomic DNA of potential yeast strain using primers NL1 and NL4 (Kurtzman and Robnett, 1998), and ITS1 and ITS4 (White et al., 1990), respectively. The PCR products were sequenced using forward and reverse primers by an automated Sanger sequencing service (Macrogen, Korea). Identity searches for the sequences were carried out using the BLAST (Altschul et al., 1990) search available in the NCBI. Sequences generated as part of this study are deposited in GenBank. Additional sequences were obtained from Kurtzman and Robnett (2003). All the sequences were aligned using the MUSCLE (Edgar, 2004) algorithm. Phylogenetic trees were reconstructed from the sequences using the Maximum Likelihood algorithm in MEGA software version 7.0 (Kumar et al., 2016). Confidence levels of the clades were estimated from bootstrap analysis based on 1000 replications.

\section{E. Optimisation of growth conditions of the potential yeast strain}

Taguchi methodology was used to find the optimum growth conditions. An $\mathrm{L}_{16}$ orthogonal array (OA) in four levels was used, which consisted of 16 different experimental trials (Elizalde-González and García-Díaz, 2010). Five selected factors, namely the amount of glucose, yeast extract and peptone, level of $\mathrm{pH}$ and inoculum size, were selected for medium optimisation. Level 1 for each factor was fixed at a low value, considering the factors' role in yeast growth in the fermentation medium. In contrast, levels 2 and 3 were deemed intermediate levels for yeast growth. Level 4 of each factor was selected at a relatively higher value range. All the trials were conducted at $30{ }^{\circ} \mathrm{C}$ for two days at $150 \mathrm{rpm}$, finally, OD was measured.

All five selected factors, their assigned levels and the experimental design are listed in Table 1 . The design for the $\mathrm{L}_{16}$ OA was developed and analysed using "MINITAB 19" software. 
Table. 1: Selected factors and their assigned levels for the optimization of fermentation media

\begin{tabular}{lllll}
\hline Factors & Level 1 & Level 2 & Level 3 & Level 4 \\
\hline $\mathrm{pH}$ & 2.5 & 4.5 & 5.5 & 6.5 \\
Inoculum size $(\mu \mathrm{1} / 100 \mathrm{ml})$ & 250 & 500 & 750 & 1000 \\
Yeast extract $(\mathrm{g} / 100 \mathrm{ml})$ & 0.25 & 0.5 & 0.75 & 1.0 \\
Peptone $(\mathrm{g} / 100 \mathrm{ml})$ & 0.5 & 1.0 & 1.5 & 2.0 \\
Glucose $(\mathrm{g} / 100 \mathrm{ml})$ & 1.0 & 2.0 & 3.0 & 4.0 \\
\hline
\end{tabular}

\section{F. Preparation of yeast extract from identified potential yeast isolate}

The potential yeast strain was cultured in $250 \mathrm{ml}$ Erlenmeyer flasks containing $100 \mathrm{ml}$ medium under optimum growth conditions which were determined in a growth optimisation experiment. The inoculated flasks were incubated in an orbital shaker at $30{ }^{\circ} \mathrm{C}$ for two days at $150 \mathrm{rpm}$. The yeast cells were harvested by centrifugation at $8000 \mathrm{rpm}$ for 10 min at ambient temperature. The pellet was re-suspended in phosphate-buffered saline and centrifuged again at the same conditions. The resulting pellet volume was estimated, and aliquots of $15 \%(\mathrm{w} / \mathrm{v})$ suspension of the yeast slurry in sterile deionised water was prepared under aseptic conditions in a $250 \mathrm{~mL}$ flask. The yeast cell disruption was carried out in two different methods. In one method, the aliquots were subjected to autolysis, and the $\mathrm{pH}$ level was adjusted to 6.0 with $1 \mathrm{~N} \mathrm{NaOH}$. For the second method, papain [1 \% (w/v) final concentration] (Papain from papaya latex, SigmaAldrich) was added to the aliquots, and the $\mathrm{pH}$ was adjusted to 6.0. The flasks were placed in a shaking water bath at a
10 min at $4{ }^{\circ} \mathrm{C}$. The supernatant was used for chemical analysis. In a control experiment, baker's yeast was used instead of the yeast strain identified in this study. The total solids in the fresh yeast and yeast extract were determined by the dry weights following drying at $105^{\circ} \mathrm{C}$ until a constant mass was achieved. The total solids content was expressed as a percentage of solids recuperated in the yeast extract with respect to the total solids present in the fresh yeast. The total crude protein content was determined by the Lowry method (Lowry et al., 1951).

\section{RESULTS AND DISCUSSION}

In this study, fifty-five different yeast strains were initially isolated from yeast sediments based on the diversity in the colony and cell morphology. The mean cell size of the isolated strains ranged from $4.0 \mu \mathrm{m}$ to $7.8 \mu \mathrm{m}$ after $48 \mathrm{~h}$ of incubation. The yeast cell suspensions' mean optical density $(\mathrm{OD} 600 \mathrm{~nm})$ was between 0.1 and 3.99 in three days of incubation (Figure 1). Since the cell size is a reasonable estimation of the protein content of yeast (Alberghina et al., 1998), the strain that had the largest cell and maximum optical density was selected as potential yeast for further study. The strain A3, isolated from the toddy sample collected in Achchuvely, showed the highest diameter (7.5 \pm $0.3 \mu \mathrm{m})$ and density $(3.49 \pm 0.5)$ at the tested growth conditions. The strain showed fermentation in a medium incorporated with sucrose, D-galactose, glucose, lactose or maltose. But it failed to grow in Raffinose medium (Table 2). Similarly, carbon sources such as glucose, galactose, inulin, sucrose, maltose, ethanol and L-arabinose were assimilated. However, growth was not observed in the assimilation medium incorporated with mannitol, ribose, myo-inositol, lactose, xylose, D-arabinose, glycerol. The strain did not show growth and utilisation of urea. Among the different

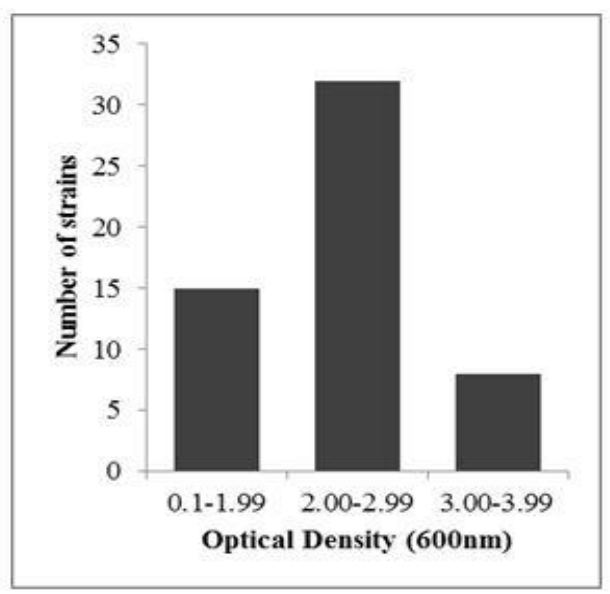

(b)

Fig. 1: Characters used to screen isolated fift five yeast strains. (a) Cell diameter $(\mu \mathrm{m})$ and (b) optical density.

constant temperature of $55^{\circ} \mathrm{C}$ at $100 \mathrm{rpm}$. After $24 \mathrm{~h}$, the flasks were heated at $85{ }^{\circ} \mathrm{C}$ for 15 min then cooled down to room temperature and finally, centrifuged at 10,000 rpm for tested growth temperatures, the strain showed maximum growth at $30{ }^{\circ} \mathrm{C}$. 
Even though biochemical characteristics have been used in yeast taxonomy, identification of yeast species entirely based on morphological traits and physiological abilities is laborious and time-consuming (Carvalho et al., 2005; Kawahata et al., 2007). Furthermore, it is also difficult to distinguish some closely related species. In contrast, gene sequence comparisons offer the opportunity to resolve closely related species, as well as more distantly related taxa. As the ITS sequences are commonly used to determine species, often in conjunction with those from the D1/D2 LSU rRNA gene (Kurtzman et al., 2011b), both of these regions were amplified in the present study and sequenced. Amplification of the ITS region (including 5.8S rRNA gene) and the LSU rRNA gene D1/D2 domains of the potential yeast strain A3 yielded $841 \mathrm{bp}$ and 615 bp PCR products, respectively. The sequences were deposited in the GenBank database with accession numbers MT322849 (for ITS region) and MT322857 (for D1/D2 domains). DNA homology search in BLAST showed $>99 \%$ sequence identity (with $100 \%$ query coverage) with Saccharomyces cerevisiae (baker's yeast).

Phylogenetic analysis of the two sequences with sequences retrieved from the GenBank database demonstrated that the strains were clustered closely with Saccharomyces cerevisiae strains. Both clades were obtained with high (> 80\%) bootstrap support values (Figure 2 and 3). Based on the above results, the potential yeast strain A3 was confirmed as a strain of Saccharomyces cerevisiae.

Table. 2: Characteristic feature of the selected yeast strain

\begin{tabular}{|c|c|}
\hline Character assessed & $\begin{array}{l}\text { Observation } \\
\text { in the isolate }\end{array}$ \\
\hline \multicolumn{2}{|l|}{ Colony characters } \\
\hline Colour & White \\
\hline Form & Circular \\
\hline Margin & Entire \\
\hline Surface & Smooth \\
\hline Texture & Mucoid \\
\hline Elevation & Convex \\
\hline \multicolumn{2}{|l|}{ Cell morphology } \\
\hline Shape & Oval \\
\hline Size & $7.5 \pm 0.3 \mu \mathrm{m}$ \\
\hline \multicolumn{2}{|l|}{ Carbohydrate fermentation } \\
\hline $\begin{array}{l}\text { Sucrose, D-galactose, Glucose, Lactose } \\
\text { and Maltose }\end{array}$ & Positive \\
\hline Raffinose & Negative \\
\hline \multicolumn{2}{|l|}{ Carbon assimilation } \\
\hline $\begin{array}{l}\text { Glucose, Galactose, Inulin, Sucrose, } \\
\text { Maltose, Ethanol, L-arabinose }\end{array}$ & Positive \\
\hline $\begin{array}{llr}\text { Mannitol, } & \text { Ribose, } & \text { Myo-Inositol, } \\
\text { Lactose, } & \text { Xylose, } & \text { D-arabinose, } \\
\text { Glycerol } & \end{array}$ & Negative \\
\hline Urea hydrolysis & Negative \\
\hline Growth temperature & $30^{\circ} \mathrm{C}$ \\
\hline$O_{600 \mathrm{~nm}}$ & $3.49 \pm 0.5$ \\
\hline
\end{tabular}

It is well documented that the macromolecular composition of growing microbial cells varies in relation to the growth rate (Villadsen and Nielsen, 2011; Zakhartsev and Reuss, 2018). Therefore, Taguchi L16 orthogonal experiment design was used to determine the growth parameters needed for the optimal growth of strain A3. The model was highly significant considering its $r^{2}=0.973$. Based on the results obtained in this analysis, the effect of each test media component on the growth of the yeast can be ranked as $\mathrm{pH}>$ glucose $>$ inoculum size $>$ peptone $>$ yeast extract (Table 3 ). The highest delta value $(0.4125)$ was obtained for the $\mathrm{pH}$ of the medium when the $\mathrm{pH}$ value was increased to 5.5 . The ANOVA results also revealed $\mathrm{pH}$ of the medium was the significant factor $(\mathrm{p}=0.011)$ compared to other tested factors.

Figure 4 illustrates the optimum conditions required for yeast growth. The optimum composition for $100 \mathrm{~mL}$ medium included $3 \mathrm{~g}$ of glucose, $2 \mathrm{~g}$ of peptone, and $0.75 \mathrm{~g}$ of yeast extract. The $\mathrm{pH}$ of the medium needed to be 5.5 and the initial inoculum was $500 \mu \mathrm{l}$. The confirmation experiment is a crucial step and is highly recommended by Taguchi to verify the experimental results (Ross, 1996).

In this study confirmation experiments were conducted by using optimised factors and levels. The average of the results from the confirmation experiment is compared with the predicted average based on the parameters and levels tested. The obtained OD600 was 7.89 in the confirmation experiment while the amount of predicted value of the design was 8.28. The quantity of resulting yeast extract depends on factors such as cell disruption method, temperature, $\mathrm{pH}$, duration of disruption and amount of yeast cell.

Table. 3: Effect of growth factors and their assign level on the mean growth $\left(\mathrm{OD}_{600}\right)$ of yeast strain

\begin{tabular}{llllll}
\hline Level & $\mathbf{p H}$ & $\begin{array}{l}\text { Inoculum } \\
\text { size }\end{array}$ & $\begin{array}{l}\text { Yeast } \\
\text { extract }\end{array}$ & Peptone & Glucose \\
& & & & & \\
\hline $\mathbf{1}$ & 0.2508 & 0.5172 & 0.5198 & 0.4543 & 0.4630 \\
$\mathbf{2}$ & 0.6315 & 0.6178 & 0.5695 & 0.5685 & 0.5045 \\
$\mathbf{3}$ & 0.6633 & 0.5713 & 0.5873 & 0.5755 & 0.6262 \\
$\mathbf{4}$ & 0.6355 & 0.4748 & 0.5045 & 0.5827 & 0.5872 \\
Delta & 0.4125 & 0.1430 & 0.0828 & 0.1285 & 0.1632 \\
Rank & 1 & 3 & 5 & 4 & 2 \\
\hline
\end{tabular}


In this study, cell disruption was carried out by the autolysis method with or without papain, and baker's yeast was used as a control. The autolysis temperature, $\mathrm{pH}$ and papain concentration were not optimised in this study. But these

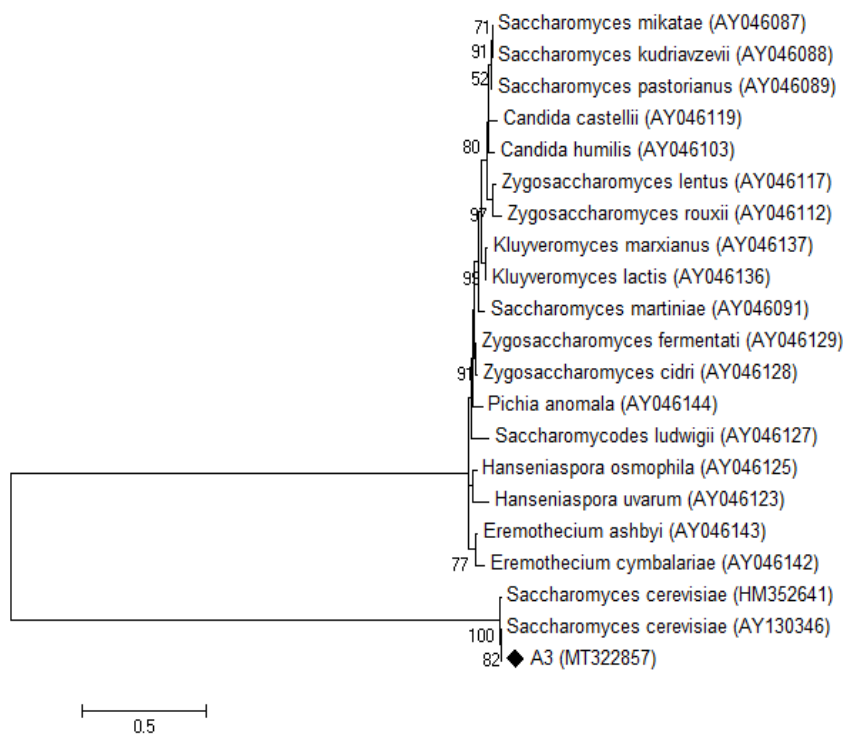

Fig. 2: Phylogenetic tree based on the LSU rRNA gene D1/D2 domains sequences showing the position of potential yeast strain A3 among related species. The evolutionary history was inferred by using the Maximum Likelihood method based on the Kimura 2-parameter model. A discrete Gamma distribution was used to model evolutionary rate differences among sites. Bootstrap values $>50 \%$ (based on 1000 replicates) are given at branch points. GenBank accession numbers are given in parentheses. The tree is drawn to scale, with branch lengths measured in the number of substitutions per site.

parameters were selected from several previous reports (Conway et al., 2001; Vukasinovic Milic et al., 2007; Dolińska et al., 2012). Papain can be used in concentrations that go from $0.1 \%$ to $2.5 \%$ at temperatures in the $50-60^{\circ} \mathrm{C}$ range and slightly acidic $\mathrm{pH} \sim 6$. Therefore in the present study, $1 \%$ was used for digestion. The result obtained from the experiment is given in Table 4. High solid recovery of $70.7 \%$ was obtained by papain treatment of yeast strain A3.
This solid recovery was higher than that of several previous reports (Verduyn et al., 1999; Chae et al., 2001; Vukasinovic Milic et al., 2007) with active baker's yeast or brewer's yeast and obtained using a combined treatment of proteolytic enzymes.

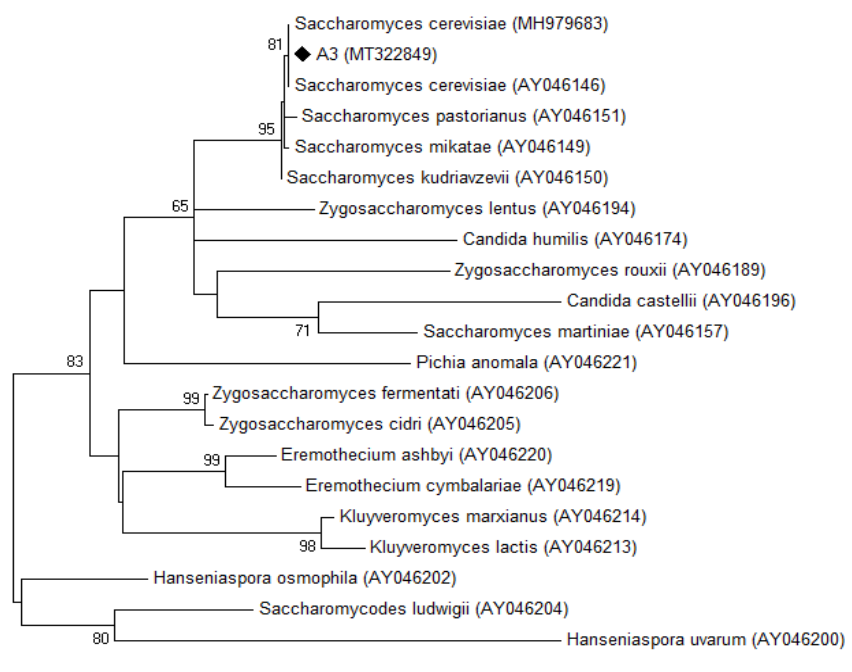

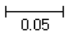

Fig. 3: Phylogenetic tree based on the ITS region (including 5.8S rRNA gene) sequences showing the position of potential yeast strain A3 among related species. The evolutionary history was inferred by using the Maximum Likelihood method based on the Kimura 2-parameter model. A discrete Gamma distribution was used to model evolutionary rate differences among sites. Bootstrap values $>50 \%$ (based on 1000 replicates) are given at branch points. GenBank accession numbers are given in parentheses. The tree is drawn to scale, with branch lengths measured in the number of substitutions per site.

In the yeast extract preparation, the yeast strain used strongly affected the recovery of the cell constituent. The strain A3, isolated from toddy sediment, yielded more total-soluble matter and total protein than the control baker's yeast. The addition of $1 \%$ papain resulted in maximum yeast extract, which contained a maximum protein content of $56.9 \mathrm{mg} / \mathrm{mL}$. This result is equal to a previous report with active baker's

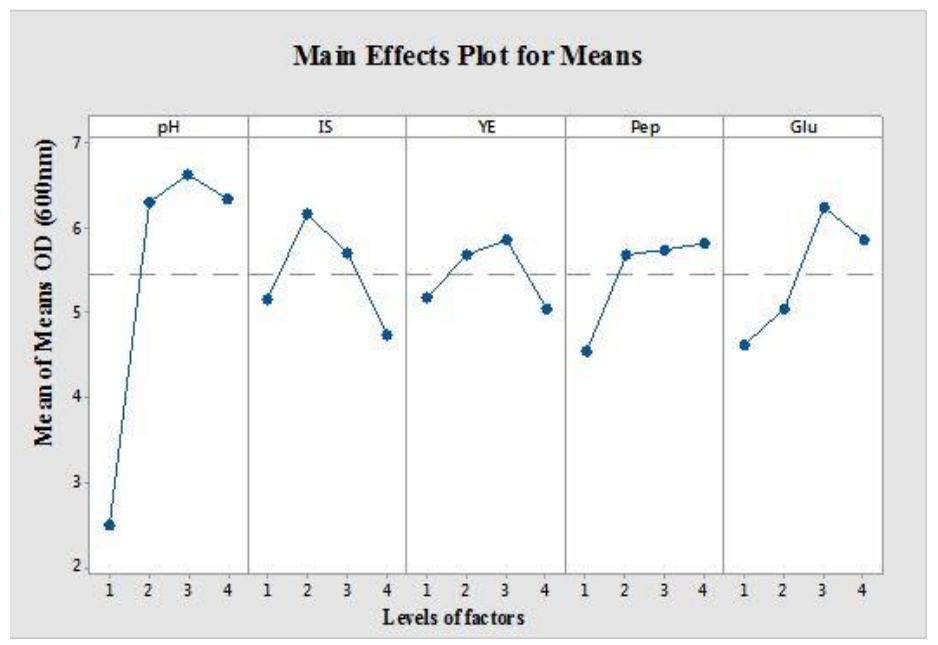

Fig. 4: The main effects of each factor on growth of the yeast strain. The detail of each level of factor is given in Table 1. $\mathrm{pH}-\mathrm{pH}$ of the initial medium; IS - inoculum size; YE - yeast extract; Pep - peptone; Glu - glucose. 
yeast treated with $2.5 \%$ papain (Vukasinovic Milic et al., 2007). Consequently, a process using an indigenous yeast strain and papain was developed to produce high-protein yeast extract. Further research is needed to develop an economically viable yeast production process based on industrial side streams or agricultural wastes as substrates.

Table. 4: Effect of yeast cells disruption

\begin{tabular}{ccccc}
\hline Method of cell & \multicolumn{2}{c}{ Soluble matter $(\%)$} & \multicolumn{2}{c}{ Protein $(\mathrm{mg} / \mathbf{m L})$} \\
\cline { 2 - 4 } disruptions & Strain A & Baker's & Strain A & Baker's \\
& & yeast & & yeast \\
\hline Autolysis & $67.6 \pm 1.5$ & $64.6 \pm 2.1$ & $54.2 \pm 1.5$ & $51.7 \pm 1.6$ \\
$\begin{array}{c}\text { Autolysis }+ \\
\text { papain }\end{array}$ & $70.7 \pm 1.2$ & $68.7 \pm 1.3$ & $56.9 \pm 1.9$ & $53.9 \pm 1.9$ \\
& & & & \\
\hline
\end{tabular}

\section{CONCLUSION}

The present study was conducted to identify yeast strain in toddy sediments with the potential to use in single-cell protein production or yeast extract preparation. The isolated strain A3, a strain of Saccharomyces cerevisiae, has been identified as a potential yeast strain. Under optimised conditions, the yeast strain A3 can yield more protein than baker's yeast. Furthermore, autolysis coupled with exogenous enzyme papain enhanced protein extraction.

\section{ACKNOWLEDGEMENT}

The authors thank Mr. P.T.J.Jashothan, Technical Officer, Department of Botany, the University of Jaffna, for assistance in part of the work conducted in the Department of Botany, University of Jaffna. The authors are highly grateful for partial financial support from Palmyrah Development Board, Jaffna, Sri Lanka.

\section{DISCLOSURE STATEMENT}

The authors reported no potential conflict of interest

\section{AUTHOR'S CONTRIBUTION}

ECJ supervised the research project and conducted experimental procedures for yeast identification. SM carried out isolation, optimisation and autolysis experiments. ECJ and SM drafted the manuscript. SSV coordinated the research activities. All authors read and approved the final manuscript.

\section{REFERENCES}

Alberghina, L., Smeraldi, C., Ranzi, B.M and Porro, D (1998). Control by nutrients of growth and cell cycle progression in budding yeast, analysed by double-tag flow cytometry. Journal of Bacteriology 180, 3864-3872. DOI: https://doi.org /10.1128/JB.180.15.3864-3872.1998

Altschul, S., Gish, W., Miller, W., Myers, E and Lipman, D (1990). Basic local alignment search tool. Journal of Molecular Biology 215, 403-410. DOI: https://doi.org /10.1016/S0022-2836(05)80360-2

Anupama, Ravindra P (2000). Value-added food: Single cell protein. Biotechnology Advances 18, 459-479. DOI: https://doi.org/10.1016/S0734-9750(00)00045-8

Boland, M.J, Rae, A.N., Vereijken, J.M., Meuwissen, M.P.M., Rutherfurd, S.M., Gruppen, H., Moughan, P.J and Hendriks, W.H (2013). The future supply of animal-derived protein for human consumption. Trends in Food Science \& Technology 29, 62-73. DOI:https://doi:10.1016/j.tifs.2012.07.002

Carvalho, C.M., Rocha, A., Estevinho, M.L.F and Choupina, A (2005). Identification of honey yeast species based on RFLP analysis of the ITS region. CYTA - Journal of Food 5, 11-17. DOI:https://doi:10.1080/11358120509487665.

Chae, H.J., Joo, H and In, M.J (2001). Utilisation of brewer's yeast cells for the production of food-grade yeast extract. Part 1: Effects of different enzymatic treatments on solid and protein recovery and flavor characteristics. Bioresource Technology 76, 253-258. DOI:https://doi:10.1016/S09608524(00)00102-4

Conway, J., Gaurdeau, H and Champagne, C.P (2001). The effect of the addition of proteases and glucanases during yeast autolysis on the production and properties of yeast extracts. Canadian Journal of Microbiology 47, 18-24. DOI:https://doi:10.1139/w00-118

Dolińska, B., Zieliński, M., Dobrzański, Z., Chojnacka, K., Opaliński, S and Ryszka, F (2012). Influence of incubation conditions on hydrolysis efficiency and iodine enrichment in baker's yeast. Biological Trace Element Research 147, 354 358. DOI:https://doi:10.1007/s12011-011-9318-0

Edgar R.C (2004). MUSCLE: Multiple sequence alignment with high accuracy and high throughput. Nucleic Acids Research 32, 1792-1797. DOI:https://doi:10.1093/nar/gkh340

Elizalde-González, M.P and García-Díaz, L.E (2010). Application of a Taguchi L16 orthogonal array for optimising the removal of Acid Orange 8 using carbon with a low specific surface area. Chemical Engineering Journal 163, 55-61. DOI:https://doi:10.1016/j.cej.2010.07.040

Frazier, W and Westhoff, D (1988). Food Microbiology. McGraw Hill Publishing Company Limited, New York. 
Hongpattarakere, T and H-kittikun, A (1995). Optimisation of single-cell-protein production from cassava starch using Schwanniomyces castellii. World Journal of Microbiology \& Biotechnology 11, 607-609. DOI:https://doi.org/10.1007/BF00360999

Kawahata, M., Fujii, T and Iefuji, H (2007). Intraspecies diversity of the industrial yeast strains Saccharomyces cerevisiae and Saccharomyces pastorianus based on analysis of the sequences of the Internal Transcribed Spacer ( ITS ) regions and the D1 / D2 region of 26S rDNA. Bioscience, Biotechnology, and Biochemistry 71, 1616-1620. DOI:https://doi:10.1271/bbb.60673

Kollar, R., Sturdik, E and Farkas, V (1991). Induction and acceleration of yeast lysis by addition of fresh yeast autolysate. Biotechnology Letters 13, 543-546. DOI:https://doi.org/10.1007/BF01033406

Kumar, S., Stecher, G and Tamura, K (2016). MEGA7: Molecular evolutionary genetics analysis version 7.0 for Bigger Datasets. Molecular Biology and Evolution 33, 18701874. DOI:https://doi:10.1093/molbev/msw054.

Kurtzman, C.P., Fell, J.W., Boekhout, T and Robert, V (2011a). Methods for isolation, phenotypic characterisation and maintenance of yeasts, pp. 87-110. In: Kurtzman, C.P., Fell, J.W and Teun B. (Ed.) The Yeasts, a Taxonomic Study. Elsevier Science Publishers. DOI:https://doi.org/10.1016/B978-0-444-52149-1.00007-0

Kurtzman, C.P., Fell, J.W and Boekhout, T (2011b). Gene sequence analyses and other DNA-based methods for yeast species recognition, pp. 137-144. In: Kurtzman, C.P., Fell, J.W and Teun, B. (Ed.). The Yeasts, a Taxonomic Study. Elsevier Science Publishers. DOI:https://doi.org/10.1016/B978-0-444-52149-1.00010-0

Kurtzman, C.P and Robnett, C.J (1998). Identification and phylogeny of ascomycetous yeasts from analysis of nuclear large subunit (26S) ribosomal DNA partial sequences. Antonie van Leeuwenhoek 73, 331-371. DOI:https://doi:10.1023/A:1001761008817

Kurtzman, C.P and Robnett, C.J (2003). Phylogenetic relationships among yeasts of the 'Saccharomyces complex' determined from multigene sequence analyses. FEMS Yeast Research 3, 417-432. DOI:https://doi:10.1016/S15671356(03)00012-6

Lapeña, D., Kosa, G., Hansen, L.D., Mydland, L.T., Passoth, V., Horn, S.J and Eijsink, V.G.H (2020). Production and characterisation of yeasts grown on media composed of spruce - derived sugars and protein hydrolysates from chicken by products. Microbial Cell Factories 19 . DOI:https://doi.org/10.1186/s12934-020-1287-6
Lowry, O.H., Rosebrough, N.J., Farr, A.L and Randall, R.J (1951). Protein measurement with the folin phenol reagent. Journal of Biological Chemistry 193, 265-275.

Nasseri, A.T., Rasoul-Amini, S., Morowvat, M.H and Ghasemi, Y (2011). Single cell protein: Production and process. American Journal of Food Technology 6, 103-116. DOI:https://doi.org/10.3923/ajft.2011.103.116

Ritala, A., Häkkinen, S.T., Toivari, $M$ and Wiebe, M.G (2017). Single cell protein — state-of-the-art, industrial landscape and patents 2001-2016. Frontiers in Microbiology 8. DOI:https://doi:10.3389/fmicb.2017.02009

Ross, P.J (1996). Taguchi techniques for quality engineering.McGraw-Hill Publishing Company Limited, New York.

Senses-ergul, S., Reka, A., Agnes, B Tibor, D (2006). Characterisation of some yeasts isolated from foods by traditional and molecular tests. International Journal of Food Microbiology 108, 120-124. DOI:https://doi:10.1016/j.ijfoodmicro.2005.10.014

Sugimoto, H (1974). Synergistic effect of ethanol and sodium chloride on autolysis of baker's yeast for preparing food-grade yeast extracts. Journal of Food Science 39, 939942.

Tanguler, $H$ and Erten, $H$ (2008). Utilisation of spent brewer' s yeast for yeast extract production by autolysis: The effect of temperature. Food and Bioproducts Processing 86, 317-321. DOI:https://doi:10.1016/j.fbp.2007.10.015

Taran, M and Bakhtiyari, S (2013). Optimisation of singlecell protein production from textile effluent at extreme conditions. Toxicological \& Environmental Chemistry 95, 110-117.

DOI:https://doi.org/10.1080/02772248.2012.745861

Theivendirarajah, K and Chrystopher, R.K (1987). Microflora and microbial activity in palmyrah (Borassus flabellifer) palm wine in Sri Lanka. World Journal of Microbiology \& Biotechnology 3, 23-31.

Verduyn, C., Suksomcheep, A and Suphantharika, M (1999). Effect of high pressure homogenisation and papain on the preparation of autolysed yeast extract. World Journal of Microbiology \& Biotechnology 15, 57-63. DOI:https://doi.org/10.1023/A:1008818511497

Villadsen, J and Nielsen, J (2011). Bioreaction Engineering Principles. Springer Science and Business Media, Inc.

Vukasinovic Milic, T., Rakin, $\mathrm{M}$ and Siler-Marinkovic, S (2007). Utilisation of baker's yeast (Saccharomyces cerevisiae) for the production of yeast extract: effects of different enzymatic treatments on solid, protein and 
carbohydrate recovery. Journal of Serbian Chemical Society 72, 451-457. DOI:https://doi:10.2298/JSC0705451V

White, T., Bruns, T., Lee, S and Taylor, J.W (1990). Amplification and direct sequencing of fungal ribosomal RNA genes for phylogenetics, pp. 315-322. In: Innis, M.A., Gelfand, D.H., Sninsky, J.J and White, T.J. (Ed.) PCR Protocols. Academic Press, Inc.

Zakhartsev, M and Reuss, M (2018). Cell size and morphological properties of yeast Saccharomyces cerevisiae in relation to growth temperature. FEMS Yeast Research 18, 1-16. DOI:https://doi:10.1093/femsyr/foy052. 